\title{
Wood used by Stradivari and Guarneri
}

\section{The material used by the old masters to make exquisite violins may have been chemically manipulated.}

Whether or not the great Italian violin-makers used wood that had been chemically processed in order to preserve it and enhance the instrument's sound quality has long been a contentious issue ${ }^{1,2}$. Here we use nuclear magnetic resonance and infrared spectroscopy to analyse organic matter in wood taken from antique instruments made by Stradivari and Guarneri del Gesu. Our results indicate that the wood used by the masters could indeed have been chemically treated, a technique that may inspire an approach to violin making that is more chemistry-based.

Maple wood samples from the interior of the instruments' back plates were obtained as thin shavings during the repair of cracks. The instruments were a violin by Stradivari, dated 1717; a cello by Stradivari (1731); a violin by Guarneri del Gesu (1741); a violin by Gand-Bernardel of Paris (1840s); and a viola by Henry Jay of London (1769). For comparison, we used recent tone woods from Bosnia and central Europe.

Figure 1a shows ${ }^{13} \mathrm{C}$ solid-state nuclear magnetic resonance (NMR) spectra of the different wood samples, recorded (see supplementary information) and interpreted as described ${ }^{3,4}$. The spectra differ at the following points: the small peaks attributed to the acetyl carbons at 18 and 170 p.p.m.; the small methoxy peak at 56 p.p.m.; and the main lignin peaks at 135 and 155 p.p.m. The most significant difference is shown by the Guarneri sample as a decrease in all of these peaks. The spectrum of

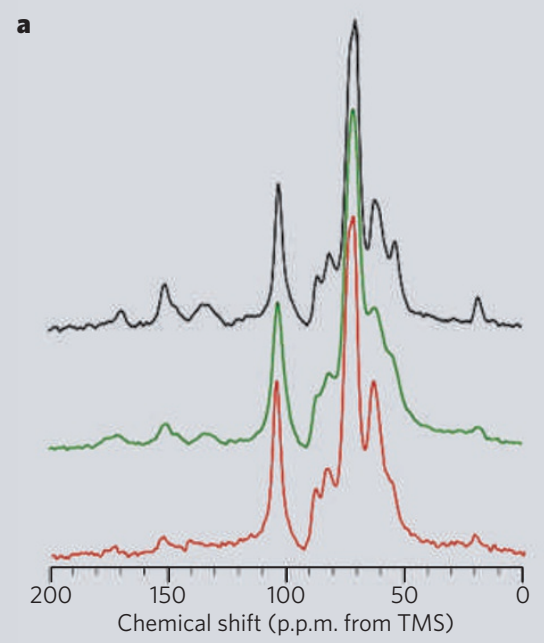

the Stradivarius violin shows close similarities to that of the Guarneri, whereas the deviations of the Stradivari cello wood from the recent Bosnian maple are only slightly different from those of the old English and French instruments, and from those generated by boiling and baking the Bosnian maple sample (for details, see supplementary information).

Attenuated total reflection Fourier-transform infrared (FTIR) spectra ${ }^{5}$ were obtained for recent Bosnian maple, the Guarneri sample and the Stradivari violin sample (Fig. 1b). The differences between these spectra are obvious at several peaks, particularly in the carbonyl region at $1,730 \mathrm{~cm}^{-1}$ to $1,650 \mathrm{~cm}^{-1}$ and at $1,237 \mathrm{~cm}^{-1}$. The increase in absorption at around $1,650 \mathrm{~cm}^{-1}$ may be caused by the formation of quinones from lignin by oxidation $^{6}$. The spectra of both violins also differ from that of the Stradivari cello, which in turn differs only slightly from those of Jay and GandBernardel and from the boiled-baked Bosnian maple. (See supplementary information for spectra and statistical analysis of their significance.) We found no evidence of potassium

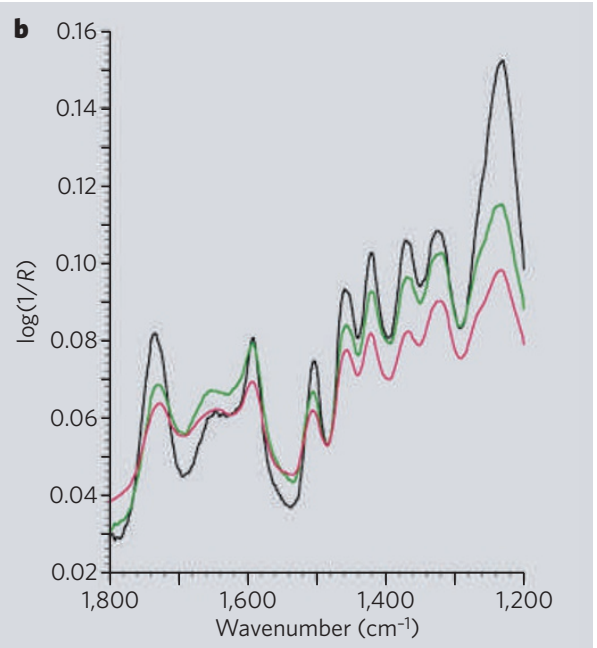

Figure 1 | Spectroscopy of maple wood samples from antique violins. a, ${ }^{13} \mathrm{C}$ solid-state NMR spectra. TMS, tetramethylsilane standard. $\mathbf{b}$, Attenuated total reflection Fourier-transform infrared spectra. Black trace, recent untreated Bosnian maple; green, violin of Stradivari; red, violin of Guarneri del Gesu. Conditions and statistical analysis are described in supplementary information.

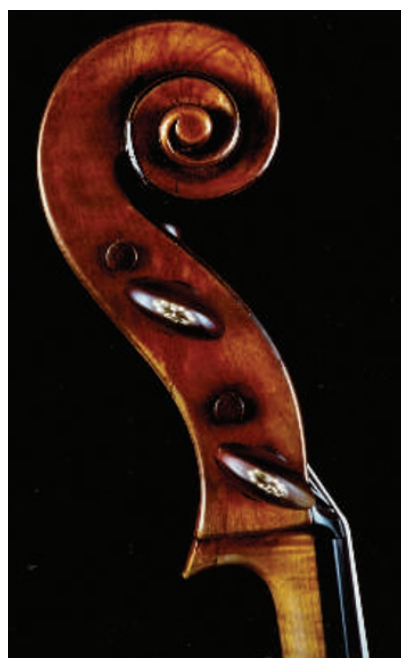

What gives this Stradivari cello its characteristic sound? silicate $^{7}$ in any of our antique samples.

By these methods, the violin by Guarneri and, to a slightly lesser degree, the Stradivari stand out against the other standards. Our results support the idea that chemical treatments, such as oxidation and hydrolysis, were used in making these violins and, to a much lesser extent, the Stradivari cello. In the case of the cello, the English viola and the French violin, natural ageing cannot be ruled out as a cause of the chemical changes. The effects may also be related to the unusual mineral composition of the wood in these instruments, which remains to be investigated.

However, the observed differences are likely to have originated from a regional practice of wood preservation that affected the mechanical and acoustical properties of the wood ${ }^{2,8}$. Our case studies may inspire a more chemistrybased approach to violin-making.

Joseph Nagyvary ${ }^{\star}$, Joseph A. DiVerdi†, Noel L. Owent, H. Dennis Tolley§

*Department of Biochemistry, Texas A\&M University, College Station, Texas 77843, USA e-mail: nagyvary@nagyvaryviolins.com †Department of Chemistry, Colorado State University, Fort Collins, Colorado 80523, USA Departments of $\div$ Chemistry and Biochemistry, §Statistics, Brigham Young University, Provo, Utah 84602, USA

1. Gough, C. Phys. World http://physicsweb.org/articles/ world/13/4/8 (April 2000).

2. Nagyvary, J. Edu. Chem. 42, 96-98 (2005)

3. Kolodziejski, W., Frye, J. S. \& Maciel, G. E. Anal. Chem. 54, 1419-1424 (1982)

4. Kosikova, B., Hricovini, M. \& Cosentino, C. Wood Sci. Technol. 33, 373-380 (1999).

5. Orton, C. R., Parkinson, D. Y., Evans, P. D. \& Owen, N. L. Appl. Spectrosc. 58, 1265-1271 (2004).

6. Anderson, E. L., Pawlak, Z., Owen, N. L. \& Feist, W. C. Appl. Spectrosc. 45, 641-647 (1991).

7. Sacconi, S. F. I "Segreti" di Stradivari (Libreria del Convegno, Cremona, 1972).

8. Haines, D. W. Catgut Acoust. Soc. Newslett. 33, 19-23 (1980).

Supplementary information accompanies this communication on Nature's website.

Received 18 July; accepted 8 November 2006. Competing financial interests: declared none. doi: $10.1038 / 444565 a$ 